\title{
Optimal Electricity Generation Expansion to Achieve Non-Conventional Renewable Energy Targets
}

\author{
W. D. Prasad and Priyantha D.C. Wijayatunga
}

\begin{abstract}
Renewable Portfolio Standard (RPS) is rapidly emerging as a popular mechanism among policy makers to increase the penetration of renewable in the electricity markets, requiring the electricity supply industry to include a minimum threshold level of electricity generation from renewable energy sources. Sri Lankan energy policy has set a target of $10 \%$ of grid electricity by 2015 to come from mini-hydro, biomass including dendro power and wind energy, which have been identified as the three leading, sustainable, non-conventional forms of renewable energy promoted in Sri Lanka for electricity generation to feed into the national grid.
\end{abstract}

The present installed capacity of grid-connected non-conventional renewable energy based electricity generation in Sri Lanka is around $100 \mathrm{MW}$ and these plants are mainly connected to the primary distribution system. All these plants contribute to the nation's energy requirement generating only a small fraction of total generation amounting to approximately $2.5 \%$. Further the long-term least-cost power generation expansion plan has given rise to the installation of oil-fired and coal-fired thermal plants to meet the increasing demand without giving adequate consideration to the non-conventional technologies as supply-side options.

The study presented in this paper investigates the impact of the RPS of $10 \%$ on the least-cost power generation expansion plan considering aforementioned renewable technologies as supply-side options together with their technical potential and economic feasibility. The paper also examines the impact on emissions with this new renewable energy policy. It has been determined that this target can be achieved with an additional cost of US\$ 93.18 million on the government by 2015 . The results also show that mini-hydro is the only mature non-conventional technology. Wind power and dendro power require substantial government subsidies if they are to play a role in RPS.

Keywords: Energy Policy, Renewable Portfolio Standards

\section{Introduction}

Renewable PortfolioStandard (RPS) requires the electricity sector to include a minimum amount of electricity from renewable energy sources. It is one of a number of policy instruments that can be used together to increase the production of electricity from renewable energy sources that are higher-cost, but have social, economic and environmental benefits. Support for renewable energy is currently needed since they are usually not yet financially competitive with conventional sources because of: subsidies to conventional sources, minimal pollution charges for conventional sources and newness of many nonconventional renewable technologies. Mechanisms normally used to support renewable electricity generation include direct financial support, such as capital grants and higher fixed tariffs, indirect support to accelerate the commercialization of renewable energy and pollution charges on conventional sources [9], [11].
However RPS, a new policy intervention is rapidly gaining popularity among policy makers. There are three major reasons for the growing popularity of the RPS [11].

- RPS maintains continuous incentives for renewable energy based producers to seek cost reductions and can be designed to ensure that these cost reductions are passed on to consumers.

- RPS can be directly linked to government policy targets since it ensures the attainment of a specific market share.

- The RPS minimizes the government involvement relative to other measures.

\footnotetext{
Eng. W. D. Prasad', AMIE(SL),B. Sc. Eng. (Hons) (Moratuwa), Research Assistant, Department of Electrical Engineering, University of Moratuwa, Moratuwa, Sri Lanka.

Eng. (Prof.) Priyantha D. C. Wijayatunga ${ }^{2}$ C. Eng., MIE(SL)Senior Member IEEE, MIET, B.Sc. Eng. (Hons) (Moratuwa), PhD(London), DIC, Professor in Electrical Engineering, University of Moratuwa and Director General, Public Utilities Commission of Sri Lanka.
} 
Though this policy has been earlier implemented in developed countries, such as USA, Australia and many European countries, developing countries like China, India, and Thailand are also interested in the same. Sri Lankan energy policy has also set a target of $10 \%$ of grid electricity by 2015 to come from mini-hydro, biomass including dendro power and wind energy [5].

The main objective of this study is to determine the impact of this $10 \%$ RPS on the least-cost power generation expansion plan of Sri Lanka, considering these non-conventional resources based decentralized power generation options such as mini-hydropower for which there is a significant potential, wind generation and dendro thermal, which have gained increased interest in recent years as supply-side options. The study also determines the cost to the government when achieving this target and the associated greenhouse gas and other harmful emissions from the Sri Lankan power sector. These options are examined from the point of view of Traditional Resource Planning (TRP) where only the supply-side options are considered without any demand side management.

\section{Power Sector in Sri Lanka}

Ceylon Electricity Board (CEB) is a statutory body with the responsibility of transmission and most of the generation and distribution of electric power. The total installed conventional capacity of the country is around $2240 \mathrm{MW}$; out of $1185 \mathrm{MW}$ is based on large hydropower, which is the main indigenous source of primary commercial electrical energy. Further, 150 MW Upper Kotmale hydroelectric plant under construction, is expected to be completed in 2011. The system also consists of $500 \mathrm{MW}$ of CEB owned thermal capacity, which are based on oil fired thermal generation with varying technologies such as oil steam, diesel engines, gas turbines and combined cycle plants [1].

A capacity of $534.5 \mathrm{MW}$ thermal plants (mainly diesel based) is owned by Independent Power Producers (IPPs) under 'build, own, and operate' mode [1]. Power so generated is sold to CEB. Also to meet the urgent requirements of the grid resulting from delays in implementing new generation projects and low hydro conditions during certain years, CEB resorts to the purchase of emergency power from time to time. These power plants are operated on auto diesel [10].

Also there are privately owned Small Power Producers (SPPs) who are allowed to establish power plants based on non-conventional Renewable Energy Technologies (RETs) up to a maximum capacity of $10 \mathrm{MW}$. There is a Standardized Power Purchase Agreement (SPPA) for such plants that is valid for 15 year period. The contribution of these nonconventional RETs in the context of total energy production is still at a relatively low value in Sri Lanka. Renewable sources of energy that have the technical potential for development in Sri Lanka for electricity generation are biomass including dendro power, small-scale hydro power, solar and wind. Present grid-connected non-conventional capacity of the country is around $100 \mathrm{MW}$.

Though there is no comprehensive study conducted to ascertain the total potential of these renewable technologies, CEB records show that $400 \mathrm{MW}$ of total mini-hydro capacity can be developed to feed the medium voltage distribution system [1]. It has also been estimated that it is possible to have $10000 \mathrm{GWh}$ of domestically sourced electricity annually from about $1200 \mathrm{MW}$ of small ( 1 to $10 \mathrm{MW}$ ) wood-fuelled thermal power stations located throughout the country [3]. According to the wind maps created by National Renewable Energy Laboratory (NREL), $50000 \mathrm{MW}$ of technical potential of wind power exists in Sri Lanka [3]. But additional studies are required to accurately assess the economic potential of wind power, considering factors such as existing transmission grid and accessibility.

In terms of sector governance, the role of the government as the owner and the regulator of the sector are planned to be reorganized with the establishment of the Public Utilities commission of Sri Lanka (PUCSL) to regulate the sector. This new environment is likely to adopt methods of increasing non-conventional renewable energy technology penetration in the system such as Renewable Portfolio Standards (RPS). Thus the proposed power sector regulatory reforms will have a positive impact on renewable energy development. 


\section{Methodology}

The Integrated Resource Planning (IRP) model and the related software developed by Asian Institute of Technology (AIT), Bangkok for longterm electricity generation expansion planning is used in this study. This model considers both supply-side and demand-side options. It is a mixed-integer linear programming based optimization model. The model determines the least-cost mix of supply-side and demand-side options for a given planning period. In the component of the study presented in this paper only the supply-side options are considered confining the model to Traditional Resource Planning (TRP).

The objective function is to minimize the total system cost, which is the sum of supply-side costs, which consists of capacity cost of candidate power plants, as well as costs of fuel, operation and maintenance of existing and candidate power plants. Further information about this planning model is given in [7], [8].

All technically feasible generation options are included in the objective function, which optimizes the total generation cost during a planning period of 20 years. Each year is divided into two seasons and the daily chronological load curve is divided into 19 blocks in order to capture variations in electrical power demand over different periods of a day.

The study tries to achieve a target of $10 \%$ of the grid electricity by 2015 using non-conventional renewable technologies. Since these technologies are still immature in Sri Lanka, government intervention is justified in order to achieve this target within the set timescale. Therefore direct capital investment subsidies, which are the most straightforward incentive [4], are used to promote non-conventional renewable technologies due to the limitations of the planning model. Thus this study output would be to propose a plan with a minimum cost to the government.

\section{Input data and Assumptions}

The inputs to the long term generation expansion planning model used in this study are similar to those generally given to other planning models. All the data used in this study are based on actual 2005 data and were obtained from Long Term Generation Expansion Plan (LTGEP) 2006-2020 report published by Generation Planning Branch of CEB [1].

\subsection{Existing and Committed Plants}

The list of existing and committed plants consists of all generation options considered in the list of future options, excluding coal steam and dendro thermal. All plants for which funding has been already arranged and those that are at various stages of development are used as committed plants in this study. The important parameters of the existing and committed hydropower plants are given in table 1 and those of thermal plants were quoted from Table 2.6 and Table 2.7 in LTGEP in page 2-10 [1].

Table 1: Data on Existing and Committed Hydro Plants

\begin{tabular}{|l|l|l|}
\hline & \multicolumn{1}{|c|}{$\begin{array}{c}\text { All } \\
\text { Existing }\end{array}$} & $\begin{array}{c}\text { Upper } \\
\text { Kothmale }\end{array}$ \\
\hline Capacity (MW) & 1185 & 150 \\
\hline Earliest available year & 1 & 6 \\
\hline Availability & 0.98 & 0.98 \\
\hline Operating cost (US\$/MWh) & 0 & 0 \\
\hline Fixed O\&M (US\$/MW month) & 0.3286 & 0.3286 \\
\hline Energy in season 1 (MWh) & 889000 & 62000 \\
\hline Energy in season 2(MWh) & 3569000 & 456000 \\
\hline
\end{tabular}

\subsection{Electricity Demand}

The demand for electricity in the country is forecasted annually by CEB using econometric analysis and is presented in LTGEP each year. Energy forecast is initially done for three consumer categories namely domestic, industrial and general purpose (including hotels) and other categories which include religious purpose and street lighting. The final energy generation forecast is done by adding total energy losses to the sum of sector wise energy forecasts. Peak demand forecast is done by assuming a load factor of $55.2 \%$ throughout the planning period. The base case demand forecast prepared by the CEB was used in this study [1].

\subsection{Future Generation Options}

The future generations options considered for planning purposes in the Sri Lankan power system are initially screened using specific generation costs of the individual options. Based on this, eight options have been identified as candidate thermal options for expansion 
planning studies. The important parameters of these options are given in [1].

\subsection{Distributed Generation (DPG)}

The DPG options considered in this study are limited to mini-hydro, wind and dendro power plants. The total capacity of small/mini hydroelectric plants connected to the medium voltage distribution system of the country by August 2005 was around $82 \mathrm{MW}$ and $108 \mathrm{MW}$ of private plants are under construction. A $3 \mathrm{MW}$ pilot-scale wind plant is in operation in southeastern part of the country since 1999 and total installed dendro thermal capacity is around $2 \mathrm{MW}$ [1].

These non-conventional plants were also considered as supply-side options for capacity expansion. Depending on the level of acceptability of the technologies, it was assumed that mini-hydro, wind and dendro plants are added to the system in 10 MW blocks. Minihydro and wind plants were considered as nondispatchable options whereas dendro as a candidate thermal plant. Data of these plants are given in tables 2 and 3.

Table 2: Data on Candidate Nondispatchable Plants

\begin{tabular}{|l|l|l|}
\hline \multicolumn{1}{|c|}{ Plant Name } & $\begin{array}{c}\text { Mini- } \\
\text { Hydro }\end{array}$ & Wind \\
\hline Unit capacity (MW) & 10 & 10 \\
\hline Availability & 0.98 & 0.3 \\
\hline Capital cost (US\$/kW) & 1200 & 1500 \\
\hline Operating cost (US\$/MWh) & 0 & 0 \\
\hline $\begin{array}{l}\text { Fixed O\&M Cost (US\$/MW } \\
\text { per month) }\end{array}$ & 3000 & 3750 \\
\hline Life time (years) & 30 & 30 \\
\hline
\end{tabular}

\section{Table 3: Candidate Dendro Plant Data}

\begin{tabular}{|l|l|}
\hline Fuel type & Fuel wood \\
\hline Fuel consumption $(\mathrm{kg} / \mathrm{MWh})$ & 1402.1 \\
\hline Calorific value (MJ/kg) & 15 \\
\hline Capacity (MW) & 10 \\
\hline Min. operating capacity (MW) & 3 \\
\hline Availability (\%) & 0.9 \\
\hline Heat rate (MJ/kWh) & 21.03 \\
\hline Capital cost (US\$/kW) & 1400 \\
\hline Fuel cost (US\$/GJ) & 8.373 \\
\hline $\begin{array}{l}\text { Operating cost (net of fuel cost), } \\
\text { (US\$Cts/kWh) }\end{array}$ & 2 \\
\hline Fixed O\&M cost (US\$/MW month) & 4670 \\
\hline Annual maintenance hours & 1320 \\
\hline Life time & 30 \\
\hline
\end{tabular}

Also the data of the fuel types used are given in table 4.

Table 4: Fuel Costs Used in the Study

\begin{tabular}{|l|l|}
\hline Fuel Type & $\begin{array}{l}\text { Fuel Cost } \\
\text { (US\$/GJ) }\end{array}$ \\
\hline Auto Diesel & 57.33 \\
\hline Coal & 10.68 \\
\hline Fuel Oil & 33.15 \\
\hline Naphtha & 60.44 \\
\hline Residual Oil & 26.87 \\
\hline
\end{tabular}

\section{Different Planning Scenarios}

To examine the impact of $10 \%$ RPS in the power system, the study uses traditional resource planning (TRP) approach. As shown in table 5, the scenarios were selected to analyze the impact on the long term generation expansion plan and the associated economic and emission conditions.

Table 5: Planning Scenarios

\begin{tabular}{|c|l|}
\hline Scenario & Description \\
\hline 1 & Base case with new fuel prices \\
\hline 2 & $\begin{array}{l}\text { Base case with non-conventional } \\
\text { generation options. }\end{array}$ \\
\hline 3 & $10 \%$ RPS by 2015. \\
\hline 4 & $\begin{array}{l}\text { Base case without Upper-Kothmale as } \\
\text { a committed hydropower plant. }\end{array}$ \\
\hline 5 & $\begin{array}{l}\text { Clean Development Mechanism } \\
(\mathrm{CDM}) \text { impact of the Upper-Kothmale } \\
\text { project assuming US\$10 per ton of } \\
\mathrm{CO}_{2} \text { reduction }\end{array}$ \\
\hline
\end{tabular}

Energy Information Administration (EIA) forecasted fuel prices for the period $2006-2025$ was used for the study. Scenarios 2 and 3 use mini-hydro, wind and dendro as supply-side options.

\section{Results}

The data discussed in section 4 was fed to the TRP model used in the study. During the calculation of emissions in each of the scenarios analyzed in the paper, the emission factors agreed upon by the Intergovernmental Panel on Climate Change (IPCC) were used for the different generation technologies [1].

Table $6 a$ shows the plant sequence under the base case scenario where the system is planned according to the traditional approach without any additional constraints. Table $6 \mathrm{~b}$ shows the 
plant sequence when non-conventional renewable generation options are considered for generation expansion planning with their actual costs as given in tables 2 and 3 . Table $6 \mathrm{c}$ corresponds to the plant sequence under 10\% RPS by 2015. Under all these cases Upper Kothmale Hydropower Plant (UKHP) was considered as a committed plant by 2011. Thus UKHP was not considered under scenarios 4 and 5 in order to determine its CDM impact and the corresponding plant additions are given in table $6 \mathrm{~d}$.

Table 6a: Selection of Plants under Base Case

\begin{tabular}{|c|c|c|}
\hline Year & Plant Additions & $\begin{array}{c}\text { Capacity Additions } \\
\text { (MW) }\end{array}$ \\
\hline 2009 & $\begin{array}{l}1 * \mathrm{CCY}+2 \text { * } \mathrm{GT}+1 \\
* \mathrm{GT}+1 * \mathrm{GT}\end{array}$ & $\begin{array}{l}1 * 300+2 * 35+1 \\
* 75+1 * 105\end{array}$ \\
\hline 2010 & $1 * \mathrm{GT}+2$ * $\mathrm{GT}$ & $1 * 75+2 * 105$ \\
\hline 2011 & 1 * Hydro +2 * Coal & $1 * 150+2 * 300$ \\
\hline 2012 & 1 * Coal & $1 * 300$ \\
\hline 2013 & $1 *$ Coal & $1 * 300$ \\
\hline 2014 & $1 * \mathrm{Coal}$ & $1 * 300$ \\
\hline 2015 & $1 *$ Coal & $1 * 300$ \\
\hline 2016 & 1 * Coal & $1 * 300$ \\
\hline 2017 & $1 *$ Coal & $1 * 300$ \\
\hline 2018 & $1 *$ Coal & $1 * 300$ \\
\hline 2019 & $1 *$ Coal & $1 * 300$ \\
\hline 2020 & $1 *$ Coal $+3 * \mathrm{GT}$ & $1 * 300+3 * 35$ \\
\hline 2021 & 1 * Coal $+5 *$ GT & $1 * 300+5 * 35$ \\
\hline 2022 & $1 *$ Coal $+5 *$ GT & $1 * 300+5 * 35$ \\
\hline 2023 & $2 * \mathrm{Coal}$ & $2 * 300$ \\
\hline 2024 & $1 * \mathrm{Coal}+5 * \mathrm{GT}$ & $1 * 300+5 * 35$ \\
\hline 2025 & 2 * Coal +4 * GT & $2 * 300+4 * 35$ \\
\hline
\end{tabular}

Table 6b: Selection of Plants with NonConventional Generation Options

\begin{tabular}{|c|c|c|}
\hline Year & Plant Additions & $\begin{array}{c}\text { Capacity Additions } \\
\text { (MW) }\end{array}$ \\
\hline 2009 & $\begin{array}{l}1 * \mathrm{CCY}+1 \text { * GT }+1 \text { * } \\
\mathrm{GT}+1 \text { * Mini-Hydro } \\
+1 \text { * Wind }\end{array}$ & $\begin{array}{l}1 * 300+1 * 75+1 \\
* 105+1 * 10+1 \text { * } \\
10\end{array}$ \\
\hline 2010 & $\begin{array}{l}2 * \mathrm{GT}+1 * \mathrm{GT}+10 * \\
\text { Dendro }+2{ }^{*} \text { Mini- } \\
\text { Hydro }\end{array}$ & $\begin{array}{l}2 * 35+1 * 105+10 \\
* 10+2 * 10\end{array}$ \\
\hline 2011 & $1{ }^{*}$ Hydro $+2{ }^{*} \mathrm{Coal}$ & $1 * 150+2 * 300$ \\
\hline 2012 & $1 * \mathrm{Coal}$ & $1 * 300$ \\
\hline 2013 & $1 *$ Coal & $1 * 300$ \\
\hline 2014 & $1 *$ Coal & $1 * 300$ \\
\hline 2015 & $1 *$ Coal & $1 * 300$ \\
\hline 2016 & 1 * Coal & $1 * 300$ \\
\hline 2017 & $1 *$ Coal & $1 * 300$ \\
\hline 2018 & $6 * \mathrm{GT}+11$ * Mini-Hydro & $6 * 35+11 * 10$ \\
\hline 2019 & $1^{*} \mathrm{Coal}+1^{*}$ Mini-Hydro & $1 * 300+1 * 10$ \\
\hline 2020 & $1 * \mathrm{Coal}+3{ }^{*} \mathrm{GT}$ & $1 * 300+3 * 35$ \\
\hline 2021 & $2 *$ Coal & $2 * 300$ \\
\hline 2022 & $1 * \mathrm{Coal}+1 * \mathrm{GT}$ & $1 * 300+1 * 35$ \\
\hline 2023 & $\begin{array}{l}1 * \text { Coal }+6 * \text { GT }+1 \\
\text { * Mini-Hydro }\end{array}$ & $\begin{array}{l}1 * 300+6 * 35+1 \\
* 10\end{array}$ \\
\hline 2024 & $2 *$ Coal & $2 * 300$ \\
\hline 2025 & $\begin{array}{l}2 * \text { Coal }+3 * \mathrm{GT}+1 \\
{ }^{*} \text { Mini-Hydro }\end{array}$ & $\begin{array}{l}2 * 300+3 * 35+1 \\
* 10\end{array}$ \\
\hline
\end{tabular}

Table 6c: Selection of Plants under 10\% RPS by 2015

\begin{tabular}{|c|c|c|}
\hline Year & Plant Additions & \begin{tabular}{|c}
$\begin{array}{c}\text { Capacity Additions } \\
\text { (MW) }\end{array}$ \\
\end{tabular} \\
\hline 2009 & $\begin{array}{l}1 * \mathrm{CCY}+1 * \mathrm{GT}+ \\
1 * \mathrm{GT}+1 \text { * Mini- } \\
\text { Hydro }+1{ }^{*} \text { Wind }\end{array}$ & $\begin{array}{l}1 * 300+1 * 75+1 \\
* 105+1 * 10+1 \text { * } \\
10\end{array}$ \\
\hline 2010 & $\begin{array}{l}2 * \mathrm{GT}+1 * \mathrm{GT}+10 * \\
\text { Dendro }+2{ }^{*} \text { Mini- } \\
\text { Hydro }\end{array}$ & $\begin{array}{l}2 * 35+1 * 105+10 \\
* 10+2 * 10\end{array}$ \\
\hline 2011 & $1{ }^{*}$ Hydro +2 * Coal & $1 * 150+2 * 300$ \\
\hline 2012 & 1 *Coal & $1 * 300$ \\
\hline 2013 & $\begin{array}{l}2 * \mathrm{GT}+9 \text { * Dendro }+ \\
12 \text { * Mini-Hydro }+3 \text { * } \\
\text { Wind }\end{array}$ & $\begin{array}{l}2 * 35+9 * 10+12 \\
* 10+3 * 10\end{array}$ \\
\hline 2014 & $1 *$ Coal & $1 * 300$ \\
\hline 2015 & 1 * Coal + 1 * GT & $1 * 300+1 * 35$ \\
\hline 2016 & 1 * Coal & $1 * 300$ \\
\hline 2017 & 1 * Coal & $1 * 300$ \\
\hline 2018 & $1 * \mathrm{Coal}$ & $1 * 300$ \\
\hline 2019 & 1 *Coal +1 *Mini-Hydro & $1 * 300+1 * 10$ \\
\hline 2020 & $1 * \mathrm{Coal}+3 * \mathrm{GT}$ & $1 * 300+3 * 35$ \\
\hline 2021 & $\begin{array}{l}1 * \text { Coal }+4 * \text { GT }+1 \\
{ }^{*} \text { Mini-Hydro }+1 * \\
\text { Wind }\end{array}$ & $\begin{array}{l}1 * 300+4 * 35+1 \\
* 10+1 * 10\end{array}$ \\
\hline 2022 & $\begin{array}{l}1 * \text { Coal }+4{ }^{*} \mathrm{GT}+2 \\
{ }^{*} \text { Dendro }+5 * \text { Mini- } \\
\text { Hydro }\end{array}$ & $\begin{array}{l}1 * 300+4 * 35+2 \\
* 10+5 * 10\end{array}$ \\
\hline 2023 & $2 *$ Coal & $2 * 300$ \\
\hline 2024 & $\begin{array}{l}1 * \text { Coal }+4 * \mathrm{GT}+3 \\
* \text { Dendro }+1 * \text { Wind }\end{array}$ & $\begin{array}{l}1 * 300+4 * 35+3 \\
* 10+1 * 10\end{array}$ \\
\hline 2025 & $2 *$ Coal $+5 *$ GT & $2 * 300+5 * 35$ \\
\hline
\end{tabular}

Table 6d: Selection of Plants without UKHP as a Committed Plant

\begin{tabular}{|c|c|c|}
\hline Year & Plant Additions & \begin{tabular}{|c} 
Capacity Additions \\
(MW)
\end{tabular} \\
\hline 2009 & $\begin{array}{l}1 * \mathrm{CCY}+2 * \mathrm{GT}+1 \\
{ }^{*} \mathrm{GT}+1 * \mathrm{GT}\end{array}$ & $\begin{array}{l}1 * 300+2 * 35+1 \\
* 75+1 * 105\end{array}$ \\
\hline 2010 & $1 * \mathrm{GT}+2 * \mathrm{GT}$ & $1 * 75+2 * 105$ \\
\hline 2011 & 1 * Steam $+2 *$ Coal & $1 * 150+2 * 300$ \\
\hline 2012 & 1 * Coal & $1 * 300$ \\
\hline 2013 & 1 * Coal & $1 * 300$ \\
\hline 2014 & $1 *$ Coal & $1 * 300$ \\
\hline 2015 & 1 * Coal & $1 * 300$ \\
\hline 2016 & 1 * Coal & $1 * 300$ \\
\hline 2017 & $1 *$ Coal & $1 * 300$ \\
\hline 2018 & 1 * Coal & $1 * 300$ \\
\hline 2019 & 1 * Coal & $1 * 300$ \\
\hline 2020 & 1 * Coal $+3 * \mathrm{GT}$ & $1 * 300+3 * 35$ \\
\hline 2021 & $1 * \mathrm{Coal}+5 * \mathrm{GT}$ & $1 * 300+5 * 35$ \\
\hline 2022 & 1 * Coal + 5* GT & $1 * 300+5 * 35$ \\
\hline 2023 & $2 *$ Coal & $2 * 300$ \\
\hline 2024 & 1 * Coal + 5* GT & $1 * 300+5 * 35$ \\
\hline 2025 & $2 * \mathrm{Coal}+4 * \mathrm{GT}$ & $2 * 300+4 * 35$ \\
\hline
\end{tabular}


300 MW and 150 MW plants in 2009 and 2011 are the Kerawalapitiya combined cycle plant and Upper Kothmale large hydropower plant which were considered as committed plants for the long-term generation expansion planning.

\section{Analysis}

It can be seen that the Sri Lankan power system needs a rapid expansion over the coming years. Further it will be a thermal based system since the least-cost generation expansion plans under all scenarios have given rise to the installation of oil-fired and coal-fired thermal plants to meet the increasing demand.

It can also be seen that the generation system consists of a total capacity of $7155 \mathrm{MW}$ without any non-conventional generation options. This comprises $5400 \mathrm{MW}$ of coal steam and $1305 \mathrm{MW}$ of oil-fired gas turbines. Further when the UKHP is not considered as a committed plant, the least-cost generation plan leads to the installation of $150 \mathrm{MW}$ steam-oil plant in 2011.

In addition to the existing grid-connected Distributed Power Generation (DPG) options of mini-hydro, dendro and wind as given in section 4.4, these three options were also offered as candidate plants to be implemented on a realistically achievable time- scale. The total centralized generation capacity reduces to 7150 MW with a plant combination of $5400 \mathrm{MW}$ of coal steam and $1020 \mathrm{MW}$ of gas turbines when these DPG options are considered as supplyside options. Thus $285 \mathrm{MW}$ of gas turbines requirement is replaced by $280 \mathrm{MW}$ of total new non-conventional capacity comprising $170 \mathrm{MW}$ mini-hydro, $100 \mathrm{MW}$ dendro thermal and 10 MW wind plant.

When these DPG options are considered for system expansion, total non-conventional renewable electricity generation by 2015 is only $6.08 \%$ of total generation. Thus government intervention is essential in order to achieve its target of $10 \%$ of grid electricity in 2015 to come from mini-hydro, dendro and wind energy. Direct capital investment subsidies were therefore used as the method of promoting these DPG options considering the limitations of the planning model. These capital subsidies were included as negative costs to the model. Further these capital subsidies can be converted into the equivalent operating cost given the plant factors of each plant. It has been determined that this target is achievable with an additional cost of US\$ 93.18 million on the government by 2015 .

The costs and $\mathrm{CO}_{2}$ emissions of each scenario are given in table 7 . Since the projected future plant additions are all thermal based, the $\mathrm{CO}_{2}$ emissions will undoubtedly increase though still it is at a relatively low value in Sri Lanka. When DPG options are considered for system expansion, the total generation cost reduces by almost $5 \%$ following overall $\mathrm{CO}_{2}$ emission reduction of $8.14 \%$.

Table 7: Generation costs and $\mathrm{CO} 2$ emissions

\begin{tabular}{|l|c|c|}
\hline \multicolumn{1}{|c|}{ Scenario } & $\begin{array}{c}\text { Generation } \\
\text { Cost } \\
\text { (US\$ million) }\end{array}$ & $\begin{array}{c}\text { Discounted } \\
\text { CO }_{2} \\
\text { emissions } \\
\text { (kt) }\end{array}$ \\
\hline Base case & 6756.24 & 76557.09 \\
\hline $\begin{array}{l}\text { Base case with renewable } \\
\text { options (DPG) }\end{array}$ & 6422.24 & 70324 \\
\hline 10\% RPS by 2015 & 6481.28 & 68371.83 \\
\hline Base case without UKHP & 6985.64 & 78446.43 \\
\hline
\end{tabular}

The total generation cost including the cost on the government under $10 \%$ RPS scenario increases slightly than that under scenario 2 . The reduction in overall $\mathrm{CO}_{2}$ emissions under this scenario is about $2.77 \%$ at an average abatement cost of US\$ 30.25 per ton of $\mathrm{CO}_{2}$. Thus the increase in generation cost to achieve this reduction is almost $1 \%$.

Non-conventional renewable options were not considered as supply-side options during scenarios 4 and 5 in order to determine the CDM impact of UKHP plant. Further the CEB also does not consider these as supply-side options for system expansion. It was mentioned earlier that a $150 \mathrm{MW}$ steam oil plant is selected for the UKHP plant in the same year resulting 3.4\% increase in generation cost followed by a $24.7 \%$ increase in $\mathrm{CO}_{2}$ emissions compared to the base case scenario (scenario 1). This will give a CDM impact of UKHP plant as US\$ 19 million assuming a US\$ 10 per ton of $\mathrm{CO}_{2}$ emission reduction.

\section{Conclusions}

The main intention of the study presented in this paper was to examine the impact on the leastcost long-term power generation expansion plan of the new non-conventional renewable energy 
policy of the government; i.e. $10 \%$ of grid electricity by 2015 from mini-hydro, dendro power and wind energy.

From the analysis it can be concluded that minihydro, dendro power and wind energy, which are the three leading renewable based distributed power generation (DPG) options in Sri Lanka need adequate consideration as supply-side options for system expansion. Introducing aforementioned DPG technologies as supply-side options for generation planning results in overall emission reductions in Sri Lanka followed by a marginal reduction in total generation cost though these DPG options are high capital intensive plants.

Further it can also be concluded that the government target of $10 \%$ of grid electricity from DPG options by 2015 is achievable within the set time-scale. Further only the CDM benefit of the UKHP plant cannot bear the additional cost on the government in order to achieve this RPS target. Mini-hydro can be considered as the only non-conventional renewable technology which does not require additional support while wind and dendro require substantial government intervention if they are to play a role in this new target.

\section{References}

1. Ceylon Electricity Board, Long Term Generation Expansion Plan 2006 - 2020, Transmission and Generation Planning Branch, Ceylon Electricity Board, 2006.

2. Electricity Reform Act No 28, Ministry of Powe and Energy, Government of Sri Lanka, 2002.

3. Incorporating Social and environmenta Concerns in Long Term Electricity Generation Expansion Planning in Sri Lanka, Energy Forum Sri Lanka, 2006

4. Nobert Wohlgemuth, "Financial Support of Renewable Energy Systems: Investment Vs Operating Cost Subsidies", Proceedings o Norwegian Association for Energy Economics (NAEE) Conference, Norway, August 2000.

5. Power Sector Policy Guidelines, Ministry of Power and Energy, Government of Sri Lanka 2004.

6. Priyantha D.C. Wijayatunga, W.J.L.S. Fernando Ram M. Shrestha, "Impact of Distributed and Independent Power generation on Greenhouse gas Emissions: Sri Lanka", Energy Conversior and Management, Vol 45, pp. 3196-3206, 2004.

7. Ram M. Shrestha, Charles O.P. Marpaung "Integrated Resource Planning in the Powe Sector and Economy-Wide Changes ir Environmental Emissions", Energy Policy, Vol 34 pp. 3801-3811, 2006.

8. Ram M. Shrestha, Charles O.P. Marpaung "Supply- and Demand-Side Effects of Powe sector Planning with $\mathrm{CO} 2$ Mitigation Constraint in a Developing Country", Energy, Vol 27, pp 271-286, 2002

9. Simone Espey, "Renewable Portfolio Standard: A Mean for Trade with electricity from renewabl Energy Sources?", Energy policy, Vol 29, pp. 557 566, 2001.

10. Tilak Siyambalapitiya, "Sri Lanka Energy Secto Development", Proceedings of Sri Lanka Energy Day, World Energy Council Executive Assembly Sri Lanka, pp. 8-30, 2005.

11. Trent Berry, Mark Jaccard, “The renewable Portfolio Standard: Design Considerations anc an Implementation Survey", Energy Policy, Vo 29, pp. 263-277, 2001. 